\title{
Synthesis and Pharmacological Evaluation of Some 3-(4-Methoxyphenyl)- 2-substitutedamino-quinazolin-4(3H)-ones as Analgesic and Anti-inflammatory Agents
}

\author{
Veerachamy AlagarsamY* and Sankaranarayanan Murugesan \\ Medicinal Chemistry Research Laboratory, Arulmigu Kalasalingam College of Pharmacy; Anand Nagar, Krishnankovil- \\ 626 190, India. Received August 26, 2006; accepted September 28, 2006
}

\begin{abstract}
A variety of novel 3-(4-methoxyphenyl)-2-substitutedamino-quinazolin-4(3H)-ones were synthesized by reacting the amino group of 2-hydrazino-3-(4-methoxyphenyl)-quinazolin-4(3H)-one with a variety of alkyl and aryl ketones. The starting material 2-hydrazino-3-(4-methoxyphenyl)-quinazolin-4(3H)-one was synthesized from 4-methoxyaniline. The title compounds were investigated for analgesic, anti-inflammatory and ulcerogenic index activities. While the test compounds exhibited significant activity, compounds 2-(1-methylpropylidene)-hydrazino-3-(4-methoxyphenyl)-quinazolin-4(3H)-one (A1), 2-(1-ethylpropylidene)-hydrazino-3-(4-methoxyphenyl)quinazolin-4(3H)-one (A2) and 2-(1-methylbutylidene)-hydrazino-3-(4-methoxyphenyl)-quinazolin-4(3H)-one (A3) showed moderately more potent analgesic activity and the compound 2-(1-methylbutylidene)-hydrazino-3(4-methoxyphenyl)-quinazolin-4(3H)-one (A3) showed moderately more potent anti-inflammatory activity when compared to the reference standard diclofenac sodium. Interestingly the test compounds showed only mild ulcerogenic potential when compared to aspirin.
\end{abstract}

Key words quinazoline; analgesic; anti-inflammatory

Nonsteroidal anti-inflammatory drugs (NSAIDs) are commonly prescribed for the treatment of acute and chronic inflammation, pain, and fever. Most of NSAIDs that are available in market are known to inhibit isoforms, a constitutive form, COX-1 and an inducible form, COX-2 to offer therapeutic effect. However long-term clinical usage of NSAIDs are associated with significant side effects of gastrointestinal lesions, bleeding, and nephrotoxicity. Therefore the discovery of new safer anti-inflammatory drugs represents a challenging goal for such a research area. ${ }^{1-4)}$ On our going medicinal chemistry research program we found that quinazolines and condensed quinazolines exhibit potent central nervous system (CNS) activities like analgesic, antiinflammatory ${ }^{5)}$ and anticonvulsant. ${ }^{6)}$ Quinazolin-4(3H)-ones with 2,3-disubstitution is reported to possess significant analgesic, anti-inflammatory ${ }^{7,8)}$ and anticonvulsant activities. ${ }^{9}$ Earlier we have documented 2-phenyl-3-substituted quinazolines, ${ }^{10)}$ 2-methyl-3-substituted quinazolines, ${ }^{11)} 2$-methylthio3 -substituted quinazolines, ${ }^{12}$ 2,3-disubstituted quinazolines ${ }^{13)}$ they exhibited good analgesic and anti-inflammatory activities. The present work is an extension of our ongoing efforts towards the development and identification of new molecules for analgesic and anti-inflammatory activities with minimal gastrointestinal ulceration side effects. With this background in the present study we have synthesized a series of 3-(4-methoxyphenyl)-2-substitutedamino-quinazolin-4(3H)-one. The synthesized compounds were tested for their analgesic, anti-inflammatory and ulcerogenic index activities.

\section{Chemistry}

The key intermediate 3-(4-methoxyphenyl)-2-thioxo-2,3dihydro-quinazolin-4(1H)-one 4 was obtained by reacting 4 methoxyaniline (1) with carbon disulphide and sodium hydroxide in dimethyl sulphoxide to give sodium dithiocarbamate, which was methylated with dimethyl sulphate to afford the dithiocarbamic acid methyl ester (2). Compound 2 on re- flux with methyl anthranilate (3) in ethanol yielded the desired 3-(4-methoxyphenyl)-2-thioxo-2,3-dihydro-quinazolin$4(1 H)$-one (4) via the thiourea intermediate in good yield $(80 \%)$. The product obtained was cyclic and not an open chain thiourea 3a. It was confirmed by its low $R f$ value, high melting point and its solubility in sodium hydroxide solution. The IR spectrum of 4 show intense peaks at $3218 \mathrm{~cm}^{-1}$ for cyclic thio urea $(\mathrm{NH}), 1680 \mathrm{~cm}^{-1}$ for carbonyl $(\mathrm{C}=\mathrm{O})$ and $1200 \mathrm{~cm}^{-1}$ for thioxo $(\mathrm{C}=\mathrm{S})$ stretching. ${ }^{1} \mathrm{H}-\mathrm{NMR}$ spectra of 4 showed singlet at $\delta 3.88 \mathrm{ppm}$ due to $\mathrm{OCH}_{3}$ group, a multiplet at $\delta 7-8.1 \mathrm{ppm}$ for aromatic $(8 \mathrm{H})$ protons and a singlet at $\delta 10.36 \mathrm{ppm}$ indicating the presence of NH. Data from the elemental analyses have been found to be in conformity with the assigned structure. Further the molecular ion recorded in the mass spectrum is also in agreement with the molecular weight of the compound.

The 2-methysulfanyl-3-(4-methoxyphenyl)-quinazolin4(3H)-one 5 was obtained by dissolving 4 in $2 \%$ alcoholic sodium hydroxide solution and methylating with dimethyl sulphate with stirring at room temperature. The IR spectra of 5 showed disappearance of $\mathrm{NH}$ and $\mathrm{C}=\mathrm{S}$ stretching signals of cyclic thiourea. It showed a peak for carbonyl $(\mathrm{C}=\mathrm{O})$ stretching at $1683 \mathrm{~cm}^{-1}$. The ${ }^{1} \mathrm{H}-\mathrm{NMR}$ spectra of compound 5 showed singlets at $\delta 2.5 \mathrm{ppm}$ and $3.87 \mathrm{ppm}$ due to $\mathrm{SCH}_{3}$ and $\mathrm{OCH}_{3}$ respectively, a multiplet at $\delta 7.0-8.26 \mathrm{ppm}$ was observed for aromatic $(8 \mathrm{H})$ protons. Data from the elemental analyses and molecular ion recorded in the mass spectra further confirmed the assigned structure.

Nucleophilic displacement of methylthio group of $\mathbf{5}$ with hydrazine hydrate was carried out using ethanol as solvent to afford 2-hydrazino-3-(4-methoxyphenyl)-quinazolin-4(3H)one 6. The long duration of reaction $(30 \mathrm{~h})$ required might be due to the presence of bulky aromatic ring at the N-3 position, which might have reduced the reactivity of quinazoline ring system at C-2 position. The formation of $\mathbf{6}$ was confirmed by the presence of $\mathrm{NH}$ and $\mathrm{NH}_{2}$ signals at 3350 $3320 \mathrm{~cm}^{-1}$ in the IR spectrum. It also showed a peak for car- 


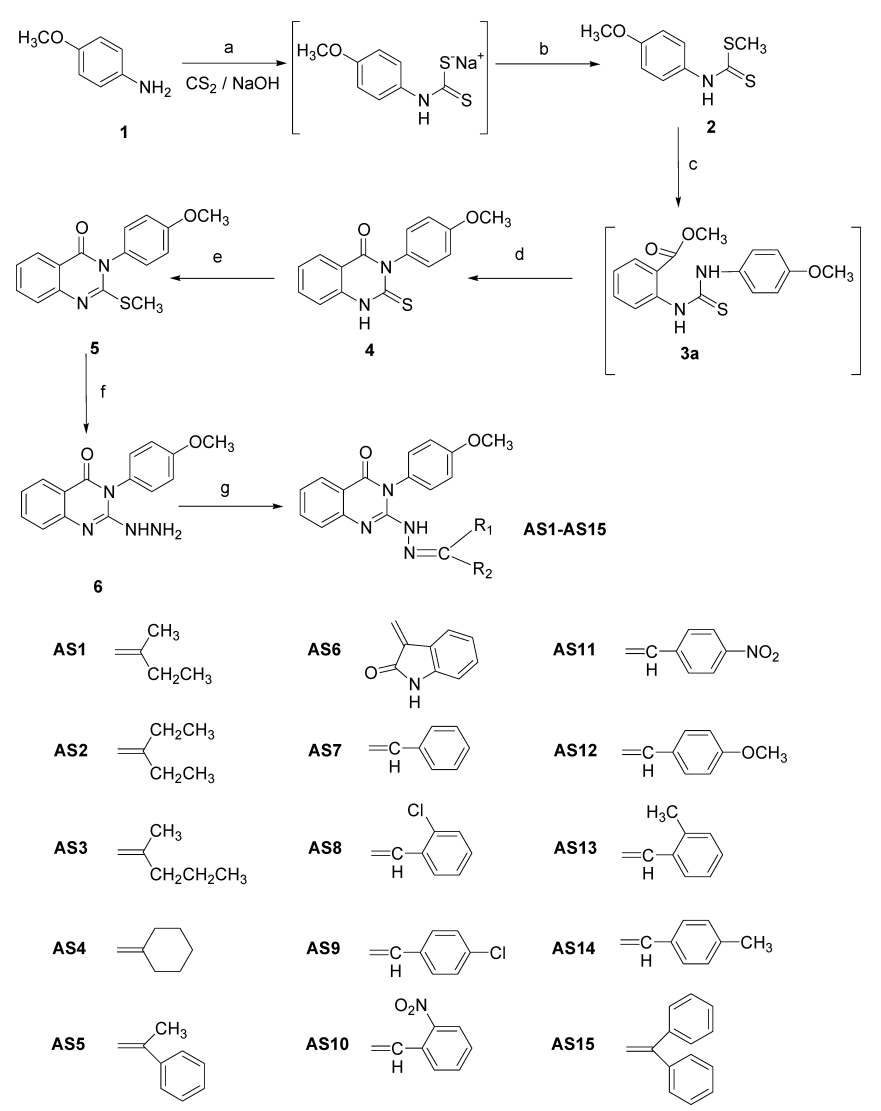

Reagents and conditions: (a) DMSO, rt, $30 \mathrm{~min}$; (b) $\left(\mathrm{CH}_{3}\right)_{2} \mathrm{SO}_{4}, 5-10{ }^{\circ} \mathrm{C}, 2 \mathrm{~h}$; (c) methyl anthranilate (3), $\mathrm{K}_{2} \mathrm{CO}_{3}$, ethanol reflux for $21 \mathrm{~h}$; (d) $10 \%$ alcoholic $\mathrm{NaOH} /$ dil. $\mathrm{HCl}$, yield $80 \%$; (e) $2 \%$ alcoholic $\mathrm{NaOH},\left(\mathrm{CH}_{3}\right)_{2} \mathrm{SO}_{4}, \mathrm{rt}, 1 \mathrm{~h}$, yield $78 \%$; (f) $\mathrm{NH}_{2} \mathrm{NH}_{2}, \mathrm{~K}_{2} \mathrm{CO}_{3}$, ethanol reflux for $22 \mathrm{~h}$, yield $74 \%$; $(\mathrm{g})\left(\mathrm{R}_{2} \mathrm{R}_{1}\right) \mathrm{CO}$; gla. $\mathrm{CH}_{3} \mathrm{COOH}$ reflux, $33 \mathrm{~h}$.

Chart 1. Synthesis of 2-(1-Methylpropylidene)-hydrazino-3-(4-methoxyphenyl)-quinazolin-4(3H)-one and Its Derivatives from 4-Methoxyaniline

bonyl $(\mathrm{C}=\mathrm{O})$ at $1674 \mathrm{~cm}^{-1}$. The ${ }^{1} \mathrm{H}-\mathrm{NMR}$ spectra of the compound 6 showed singlets at $\delta 3.79 \mathrm{ppm}, 4.95 \mathrm{ppm}$ and $8.56 \mathrm{ppm}$ due to $\mathrm{OCH}_{3}, \mathrm{NH}_{2}$ and $\mathrm{NH}$ respectively, a multiplet at $\delta 6.82-8.06 \mathrm{ppm}$ was observed for aromatic $(8 \mathrm{H})$ protons. Data from the elemental analyses have been found to be in conformity with the assigned structure. Further the molecular ion recorded in the mass spectra is also in agreement with the molecular weight of the compound.

The title compounds 3-(4-methoxyphenyl)-2-substitutedamino-quinazolin-4(3H)-ones A1-A15 were obtained by the condensation of amino group of 2-hydrazino-3-(4methoxy phenyl)-quinazolin-4(3H)-one (6) with a variety of alkyl and aryl ketones. The formation of title product is indicated by the disappearance of peak due to $\mathrm{NH}_{2}$ of the starting material in IR and ${ }^{1} \mathrm{H}-\mathrm{NMR}$ spectrum of all the compounds A1-A15. The IR and ${ }^{1} \mathrm{H}-\mathrm{NMR}$ spectrum of these compounds showed the presence of peaks due to $\left(\mathrm{N}=\mathrm{CR}^{1} \mathrm{R}^{2}\right)$ carbonyl $(\mathrm{C}=\mathrm{O}), \mathrm{NH}$ and Aryl groups. The mass spectra of the title compounds are in confirmity with the assigned structure. The mass spectra of these compounds showed molecular ion peaks corresponding to their molecular formulae. A common peak at $\mathrm{m} / \mathrm{z} 144$ corresponding to quinazolin-4-one moiety appeared in all mass spectra of compounds A1-A15. Elemental $(\mathrm{C}, \mathrm{H}, \mathrm{N})$ analysis satisfactorily confirmed elemental composition and purity of the synthesized compounds.
Table 1. Percent Analgesic Activity of Test Compounds (Tail-Flick Technique)

\begin{tabular}{|c|c|c|c|c|c|}
\hline \multirow{2}{*}{$\begin{array}{l}\text { Compound } \\
\text { code }\end{array}$} & \multirow{2}{*}{$\begin{array}{c}\text { Dose } \\
(\mathrm{mg} / \mathrm{kg})\end{array}$} & \multicolumn{4}{|c|}{ Percent analgesic activity } \\
\hline & & $30 \mathrm{~min}$ & $1 \mathrm{~h}$ & $2 \mathrm{~h}$ & $3 \mathrm{~h}$ \\
\hline \multirow[t]{2}{*}{$\mathbf{A 1}$} & 10 & $45 \pm 1.76^{*}$ & $47 \pm 1.93^{*}$ & $52 \pm 1.27^{* *}$ & $32 \pm 1.81 *$ \\
\hline & 20 & $59 \pm 1.69 * * *$ & $63 \pm 1.83^{* * *}$ & $64 \pm 1.19 * * *$ & $44 \pm 1.36^{*}$ \\
\hline \multirow[t]{2}{*}{$\mathbf{A 2}$} & 10 & $52 \pm 1.68 * *$ & $57 \pm 1.94 * *$ & $59 \pm 1.37 * * *$ & $43 \pm 1.38^{*}$ \\
\hline & 20 & $65 \pm 1.47^{* * *}$ & $70 \pm 1.81^{* * *}$ & $73 \pm 1.94 * * *$ & $48 \pm 1.04 *$ \\
\hline \multirow[t]{2}{*}{ A3 } & 10 & $46 \pm 1.92^{*}$ & $49 \pm 1.06^{*}$ & $53 \pm 1.94 * *$ & $35 \pm 1.17 *$ \\
\hline & 20 & $59 \pm 1.73^{* * *}$ & $66 \pm 1.82 * * *$ & $68 \pm 1.81 * * *$ & $46 \pm 1.72 *$ \\
\hline \multirow[t]{2}{*}{ A4 } & 10 & $35 \pm 1.05^{*}$ & $42 \pm 1.83^{*}$ & $47 \pm 160 *$ & $28 \pm 1.04 *$ \\
\hline & 20 & $51 \pm 1.37 * *$ & $54 \pm 1.20 * *$ & $55 \pm 1.38 * *$ & $36 \pm 1.29 *$ \\
\hline \multirow[t]{2}{*}{ A5 } & 10 & $39 \pm 1.61^{*}$ & $46 \pm 1.83^{*}$ & $48 \pm 1.47^{*}$ & $31 \pm 1.71 *$ \\
\hline & 20 & $52 \pm 1.03 * *$ & $55 \pm 1.82 * *$ & $56 \pm 1.91 * *$ & $38 \pm 1.73 *$ \\
\hline \multirow[t]{2}{*}{ A6 } & 10 & $37 \pm 1.98 *$ & $39 \pm 1.03^{*}$ & $41 \pm 1.44^{*}$ & $29 \pm 1.92 *$ \\
\hline & 20 & $48 \pm 1.64 *$ & $54 \pm 1.93 * *$ & $56 \pm 1.87 * *$ & $34 \pm 1.05^{*}$ \\
\hline \multirow[t]{2}{*}{$\mathbf{A} 7$} & 10 & $36 \pm 1.01 *$ & $39 \pm 1.73^{*}$ & $45 \pm 1.62 *$ & $33 \pm 1.38 *$ \\
\hline & 20 & $47 \pm 1.61 *$ & $54 \pm 1.24 * *$ & $57 \pm 1.36 * *$ & $38 \pm 1.03 *$ \\
\hline \multirow[t]{2}{*}{ A8 } & 10 & $27 \pm 1.41 *$ & $32 \pm 1.92 *$ & $36 \pm 1.71 *$ & $28 \pm 1.62 *$ \\
\hline & 20 & $35 \pm 1.93 *$ & $40 \pm 1.38^{*}$ & $44 \pm 1.15^{*}$ & $38 \pm 1.81 *$ \\
\hline \multirow[t]{2}{*}{ A9 } & 10 & $34 \pm 1.15^{*}$ & $37 \pm 1.85^{*}$ & $41 \pm 1.22 *$ & $29 \pm 1.37 *$ \\
\hline & 20 & $43 \pm 1.28 *$ & $47 \pm 1.94 *$ & $47 \pm 1.81 *$ & $33 \pm 1.72 *$ \\
\hline \multirow[t]{2}{*}{$\mathbf{A 1 0}$} & 10 & $33 \pm 1.08 *$ & $37 \pm 1.24 *$ & $42 \pm 1.74 *$ & $32 \pm 1.91 *$ \\
\hline & 20 & $45 \pm 1.85^{*}$ & $49 \pm 1.74 *$ & $53 \pm 1.79 *$ & $36 \pm 1.95 *$ \\
\hline \multirow[t]{2}{*}{ A11 } & 10 & $32 \pm 1.42 *$ & $36 \pm 1.71 *$ & $40 \pm 195^{*}$ & $29 \pm 1.69 *$ \\
\hline & 20 & $35 \pm 1.91 *$ & $46 \pm 1.85^{*}$ & $49 \pm 1.47 *$ & $35 \pm 1.54 *$ \\
\hline \multirow[t]{2}{*}{ A12 } & 10 & $35 \pm 1.63 *$ & $39 \pm 1.79 *$ & $44 \pm 1.54 *$ & $33 \pm 1.07 *$ \\
\hline & 20 & $41 \pm 1.52 *$ & $44 \pm 1.96^{*}$ & $48 \pm 1.64 * *$ & $38 \pm 1.24 *$ \\
\hline \multirow[t]{2}{*}{ A13 } & 10 & $37 \pm 1.42 *$ & $38 \pm 1.73^{*}$ & $43 \pm 1.95^{*}$ & $31 \pm 1.26^{*}$ \\
\hline & 20 & $48 \pm 1.08 *$ & $51 \pm 1.76 * *$ & $53 \pm 1.93 *$ & $38 \pm 1.84 *$ \\
\hline \multirow[t]{2}{*}{ A14 } & 10 & $38 \pm 1.08 *$ & $42 \pm 1.94^{*}$ & $43 \pm 1.54^{*}$ & $34 \pm 1.65^{*}$ \\
\hline & 20 & $47 \pm 1.45^{*}$ & $49 \pm 1.16^{*}$ & $54 \pm 1.25 * *$ & $41 \pm 1.76^{*}$ \\
\hline \multirow[t]{2}{*}{$\mathbf{A 1 5}$} & 10 & $36 \pm 1.42 *$ & $38 \pm 1.95^{*}$ & $43 \pm 1.83^{*}$ & $30 \pm 1.42 *$ \\
\hline & 20 & $42 \pm 1.37 *$ & $45 \pm 1.18^{*}$ & $49 \pm 1.46^{*}$ & $38 \pm 1.60 *$ \\
\hline Control & & $2 \pm 0.35$ & $6 \pm 0.49$ & $4 \pm 0.59$ & $4 \pm 0.91$ \\
\hline \multirow[t]{2}{*}{ Diclofenac } & 10 & $37 \pm 1.69 *$ & $43 \pm 1.42 *$ & $45 \pm 0.92 *$ & $33 \pm 0.96 *$ \\
\hline & 20 & $46 \pm 0.95^{*}$ & $55 \pm 1.16^{* *}$ & $62 \pm 1.49 * * *$ & $39 \pm 1.13 *$ \\
\hline
\end{tabular}

Each value represents the mean \pm S.D. $(n=6)$. Significance levels $* p<0.5, * * p<0.01$ and $* * * p<0.001$ as compared with the respective control.

\section{Results and Discussion}

Test for analgesic activity was performed by tail-flick technique $^{14,15)}$ using Wistar albino mice. The results of analgesic activity indicate that test compounds exhibited moderate analgesic activity at $30 \mathrm{~min}$ of reaction time; the activity increased at $1 \mathrm{~h}$ and it reached to peak level at $2 \mathrm{~h}$. Declining in activity was observed at $3 \mathrm{~h}$ (Table 1). Compound A1 with 1methylpropylidene substituent showed good activity; with the increased lipophilicity (1-ethylpropylidene group, compound A2) showed increase in activity. Replacement of 1-ethylpropylidene group with its isomer 2-pentylidene group (compound A3) retains the activity. Replacement of an alkyl chain at the 2-position with a cycloalkyl group and an aralkyl group (compounds A4 and A5 respectively) leads to moderate decrease in activity. Placement of aryl group at the N-3 position (compounds A6, A7 and A13-A15) also results in decreasing activity. Placement of electron withdrawing group at N-3 aryl ring (compounds A8-A12) leads to further decrease of activity. Compound 2-(1-ethylpropylidene)hydrazino-3-(4-methoxyphenyl)-quinazolin-4(3H)-one (A2) emerged as the most active analgesic agent and it is more potent when compared to the reference standard diclofenac sodium.

Anti-inflammatory activity was evaluated by carrageenaninduced paw oedema test in rats. ${ }^{16)}$ The anti-inflammatory activity data (Table 2 ) indicated that all the test compounds protected rats from carrageenan-induced inflammation moderately at $30 \mathrm{~min}$ of reaction time; the activity increased at $1 \mathrm{~h}$ and it reached to peak level at $2 \mathrm{~h}$. Declining in activity 
Table 2. Percent Anti-inflammatory Activity of Test Compounds (Carrageenan-Induced Paw Oedema Test in Rats)

\begin{tabular}{|c|c|c|c|c|c|}
\hline \multirow{2}{*}{$\begin{array}{l}\text { Compound } \\
\text { code }\end{array}$} & \multirow{2}{*}{$\begin{array}{c}\text { Dose } \\
(\mathrm{mg} / \mathrm{kg})\end{array}$} & \multicolumn{4}{|c|}{ Percent protection } \\
\hline & & $30 \mathrm{~min}$ & $1 \mathrm{~h}$ & $2 \mathrm{~h}$ & $3 \mathrm{~h}$ \\
\hline \multirow[t]{2}{*}{ A1 } & 10 & $35 \pm 1.15^{*}$ & $38 \pm 1.73^{*}$ & $40 \pm 1.81^{*}$ & $25 \pm 1.54^{*}$ \\
\hline & 20 & $41 \pm 1.94 *$ & $46 \pm 1.26^{* *}$ & $49 \pm 1.42 * *$ & $38 \pm 1.31 *$ \\
\hline \multirow[t]{2}{*}{ A2 } & 10 & $37 \pm 1.93 *$ & $39 \pm 1.37^{*}$ & $43 \pm 1.05^{*}$ & $30 \pm 1.82 *$ \\
\hline & 20 & $44 \pm 1.90 * *$ & $57 \pm 1.47 * * *$ & $59 \pm 1.52 * * *$ & $38 \pm 1.26^{*}$ \\
\hline \multirow[t]{2}{*}{ A3 } & 10 & $37 \pm 1.17^{*}$ & $45 \pm 1.42 *$ & $49 \pm 1.83^{*}$ & $32 \pm 1.08^{*}$ \\
\hline & 20 & $48 \pm 1.19^{* *}$ & $60 \pm 1.63 * * *$ & $65 \pm 1.45 * * *$ & $40 \pm 1.38^{*}$ \\
\hline \multirow[t]{2}{*}{ A4 } & 10 & $30 \pm 1.94 *$ & $36 \pm 1.42 *$ & $39 \pm 1.63^{*}$ & $26 \pm 1.46^{*}$ \\
\hline & 20 & $38 \pm 1.51 *$ & $46 \pm 1.94 *$ & $46 \pm 1.48^{*}$ & $31 \pm 1.63 *$ \\
\hline \multirow[t]{2}{*}{ A5 } & 10 & $34 \pm 1.18 *$ & $37 \pm 1.37 *$ & $39 \pm 1.19^{*}$ & $28 \pm 1.83^{*}$ \\
\hline & 20 & $41 \pm 1.26^{*}$ & $43 \pm 1.37^{*}$ & $46 \pm 1.26^{* *}$ & $33 \pm 1.45^{*}$ \\
\hline \multirow[t]{2}{*}{ A6 } & 10 & $29 \pm 1.15^{*}$ & $32 \pm 1.29 *$ & $35 \pm 1.16^{*}$ & $26 \pm 1.83 *$ \\
\hline & 20 & $34 \pm 1.36^{*}$ & $37 \pm 1.15^{*}$ & $38 \pm 1.71^{*}$ & $33 \pm 1.15^{*}$ \\
\hline \multirow[t]{2}{*}{ A7 } & 10 & $27 \pm 1.84 *$ & $34 \pm 1.27 *$ & $38 \pm 1.06^{*}$ & $26 \pm 1.37 *$ \\
\hline & 20 & $33 \pm 1.25^{*}$ & $42 \pm 1.47^{*}$ & $45 \pm 1.28^{*}$ & $31 \pm 1.93^{*}$ \\
\hline \multirow[t]{2}{*}{ A8 } & 10 & $24 \pm 1.41 *$ & $27 \pm 1.83^{*}$ & $29 \pm 1.52 *$ & $23 \pm 1.73 *$ \\
\hline & 20 & $29 \pm 1.82 *$ & $36 \pm 1.63 *$ & $32 \pm 1.85^{*}$ & $28 \pm 1.14 *$ \\
\hline \multirow[t]{2}{*}{ A9 } & 10 & $28 \pm 1.23 *$ & $26 \pm 1.15^{*}$ & $32 \pm 1.26^{*}$ & $24 \pm 1.93 *$ \\
\hline & 20 & $31 \pm 1.05^{*}$ & $34 \pm 1.24 *$ & $34 \pm 1.25^{*}$ & $30 \pm 1.93 *$ \\
\hline \multirow[t]{2}{*}{ A10 } & 10 & $29 \pm 1.73 *$ & $32 \pm 1.06^{*}$ & $36 \pm 1.93 *$ & $23 \pm 1.18^{*}$ \\
\hline & 20 & $36 \pm 1.05 *$ & $37 \pm 1.73^{*}$ & $39 \pm 1.39 *$ & $34 \pm 1.53 *$ \\
\hline \multirow[t]{2}{*}{ A11 } & 10 & $24 \pm 1.74 *$ & $29 \pm 1.32 *$ & $33 \pm 1.85^{*}$ & $23 \pm 1.39 *$ \\
\hline & 20 & $38 \pm 1.27 *$ & $38 \pm 1.93 *$ & $42 \pm 1.85^{*}$ & $30 \pm 1.27^{*}$ \\
\hline \multirow[t]{2}{*}{ A12 } & 10 & $26 \pm 1.18 *$ & $29 \pm 1.23 *$ & $34 \pm 1.93 *$ & $24 \pm 1.91 *$ \\
\hline & 20 & $36 \pm 1.48^{*}$ & $38 \pm 1.92 *$ & $42 \pm 1.61 *$ & $31 \pm 1.83^{*}$ \\
\hline \multirow[t]{2}{*}{ A13 } & 10 & $32 \pm 1.72 *$ & $34 \pm 1.37^{*}$ & $37 \pm 1.93 *$ & $29 \pm 1.28 *$ \\
\hline & 20 & $38 \pm 1.54 *$ & $41 \pm 1.51^{*}$ & $44 \pm 1.62 *$ & $33 \pm 1.93 *$ \\
\hline \multirow[t]{2}{*}{ A14 } & 10 & $29 \pm 1.71 *$ & $36 \pm 1.83$ & $36 \pm 1.54 *$ & $27 \pm 1.42 *$ \\
\hline & 20 & $41 \pm 1.71 *$ & $41 \pm 1.36^{* *}$ & $42 \pm 1.81^{*}$ & $37 \pm 1.62 *$ \\
\hline \multirow[t]{2}{*}{ A15 } & 10 & $29 \pm 1.05^{*}$ & $30 \pm 1.41^{*}$ & $32 \pm 1.54 *$ & $28 \pm 1.39^{*}$ \\
\hline & 20 & $38 \pm 1.54 *$ & $41 \pm 1.62 *$ & $45 \pm 1.61 *$ & $36 \pm 1.63 *$ \\
\hline Control & & $5.1 \pm 0.29$ & $6.1 \pm 0.27$ & $5.7 \pm 0.32$ & $3.2 \pm 0.93$ \\
\hline \multirow{2}{*}{ Diclofenac } & 10 & $32 \pm 0.63^{*}$ & $38 \pm 1.58^{*}$ & $39 \pm 1.97^{*}$ & $33 \pm 0.93 *$ \\
\hline & 20 & $45 \pm 1.61 * *$ & $52 \pm 0.92 * * *$ & $60 \pm 1.52 * * *$ & $42 \pm 1.36^{* *}$ \\
\hline
\end{tabular}

Each value represents the mean \pm S.D. $(n=6)$. Significance levels $* p<0.5, * * p<0.01$ and $* * * p<0.001$ as compared with the respective control.

was observed at $3 \mathrm{~h}$. The compound 2-(1-methylbutylidene)hydrazino-3-(4-methoxyphenyl)-quinazolin-4(3H)-one (A3) showed moderately more potent anti-inflammatory activity when compared to the reference standard diclofenac sodium. The compound 2-(1-ethylpropylidene)-hydrazino-3-(4methoxyphenyl)-quinazolin-4(3H)-one (A2) showed equipotent anti-inflammatory activity when compared to the reference standard diclofenac sodium.

The ulcer index of the test compounds (Table 3) reveal that the compounds with open chain aliphatic substituents (compounds A1-A3) showed negligible ulcer index, whereas aryl substituents (compounds A5-A7 and A13-A15) exhibited little increase in ulcer index and the aryl substituents containing electron withdrawing groups (compounds A8 A12) exhibited higher ulcer index over other test compounds. When compared to the reference standards aspirin (ulcer index 1.73 \pm 0.41 ) and diclofenac (ulcer index 1.65 \pm 0.59 ) the test compounds exhibited about 35 to $50 \%$ of the ulcer index of reference standards. Compounds 2-(1-ethylpropylidene)-hydrazino-3-(4-methoxyphenyl)-quinazolin-4(3H)-one (A2) and 2-(1-methylbutylidene)-hydrazino-3-(4-methoxyphenyl)-quinazolin-4(3H)-one (A3) exhibited least ulcer index $(0.57 \pm 1.37$ and $0.56 \pm 1.04$ respectively) among the test compounds which is about one third of the ulcer index of reference standards aspirin and diclofenac. The compound 2( $N^{\prime}$-(4-chloro-benzylidene-hydrazino)-3-(4-methoxyphenyl)quinazolin-4(3H)-one (A9) showed the highest ulcer index $(0.96 \pm 1.64)$ among the test compounds which is about $50 \%$ of the ulcer index of aspirin and diclofenac.
Table 3. Evaluation of Ulcerogenicity Index

\begin{tabular}{cl}
\hline \hline Compd. code & Ulcer index \\
\hline $\mathbf{A 1}$ & $0.63 \pm 1.51^{*}$ \\
$\mathbf{A 2}$ & $0.57 \pm 1.37^{*}$ \\
$\mathbf{A 3}$ & $0.56 \pm 1.04^{*}$ \\
$\mathbf{A 4}$ & $0.74 \pm 1.39^{*}$ \\
$\mathbf{A 5}$ & $0.72 \pm 1.32^{*}$ \\
$\mathbf{A 6}$ & $0.74 \pm 1.41^{*}$ \\
$\mathbf{A 7}$ & $0.81 \pm 1.72^{*}$ \\
$\mathbf{A 8}$ & $0.91 \pm 1.05^{*}$ \\
$\mathbf{A 9}$ & $0.96 \pm 1.64$ \\
$\mathbf{A 1 0}$ & $0.94 \pm 1.65^{*}$ \\
$\mathbf{A 1 1}$ & $0.92 \pm 1.47^{*}$ \\
$\mathbf{A 1 2}$ & $0.95 \pm 1.59^{*}$ \\
$\mathbf{A 1 3}$ & $0.66 \pm 1.07^{*}$ \\
$\mathbf{A 1 4}$ & $0.88 \pm 1.27^{*}$ \\
$\mathbf{A 1 5}$ & $0.69 \pm 1.36^{*}$ \\
Control & $1.05 \pm 0.32^{*}$ \\
Diclofenac & $1.65 \pm 0.59^{*}$ \\
Aspirin & $1.73 \pm 0.41^{* *}$ \\
\hline
\end{tabular}

Dose $20 \mathrm{mg}$ for test compounds, diclofenac and aspirin. Each value represents the mean \pm S.D. $(n=6)$. Significance levels $* p<0.05$ and $* * p<0.01$ as compared with the respective control.<smiles>CCN(CC)C(=S)Nn1c(-c2ccccc2)nc2ccccc2c1=O</smiles><smiles>Cc1nc2ccccc2c(=O)n1NC(=S)n1cccc1</smiles>

(8)<smiles>CCCCSc1nc2ccccc2c(=O)n1NC(=S)N(CC)CC</smiles>

(9)

Fig. 1

\section{Conclusions}

In our earlier studies ${ }^{10-13)}$ we observed that the presence of alkyl groups exhibited more analgesic and anti-inflammatory activities over aryl groups at the N-3 position. Hence in the $\mathrm{C}-2$ position also we made a substitution in such a way to increase lipophilicity of the molecule. The placement of such a group enhanced the analgesic and anti-inflammatory activities. The most active compound of the C-2 phenyl series 1diethyl-3-(2-phenyl quinazolin-3-yl-4(3H)-one) thiourea (7) (Fig. 1) showed $44 \%$ and $58 \%$ analgesic and $38 \%$ and $53 \%$ anti-inflammatory activity at the dose of 10 and $20 \mathrm{mg} / \mathrm{kg}$ respectively, at the reaction time of $2 \mathrm{~h} .{ }^{10)}$ Whereas the C-2 methyl series lead molecule 1-pyrrolidinyl-3-(2-methyl quinazolin-3-yl-4(3H)-one) thiourea (8) (Fig. 1) exhibited $50 \%$ and $65 \%$ analgesic and $44 \%$ and $60 \%$ anti-inflammatory activity at the dose of 10 and $20 \mathrm{mg} / \mathrm{kg}$ respectively at the reaction time of $2 \mathrm{~h}^{1{ }^{11)}}$ Introduction of sulphur atom at $\mathrm{C}$ 2 position in the above series i.e. by placing methylthio group at C-2 position ${ }^{12)}$ compound 1-diethyl-3-(2-methylthio quinazolin-3-yl-4(3H)-one) thiourea (9) (Fig. 1) exhibited $56 \%, 67 \%$ analgesic activity, $40 \%$ and $62 \%$ anti-inflammatory activity at 10 and $20 \mathrm{mg} / \mathrm{kg}$ respectively at the reaction time of $2 \mathrm{~h}$. The results of the analgesic and anti-inflammatory activities of the present series showed that moderate enhancement of activity. The compound A2 exhibited 59\% and 
$73 \%$ analgesic activity at 10 and $20 \mathrm{mg} / \mathrm{kg}$ dose level respectively at the reaction time of $2 \mathrm{~h}$. The compound $\mathbf{A} 3$ showed $49 \%$ and $65 \%$ anti-inflammatory activity at the dose of 10 and $20 \mathrm{mg} / \mathrm{kg}$ respectively at the reaction of $2 \mathrm{~h}$. Interestingly these compounds showed $35 \%$ of ulcer index of the reference NSAID's aspirin and diclofenac. Hence this series could be developed as a novel class of analgesic and anti-inflammatory agents. However further structural modification is planned to increase the analgesic and anti-inflammatory activities with the decreased ulcerogenic index.

\section{Experimental}

Melting points (mp) were taken in open capillaries on Thomas Hoover melting point apparatus and are uncorrected. Infrared (IR) spectra were recorded on an FT-IR Perkin-Elmer spectrometer. The ${ }^{1} \mathrm{H}$-NMR spectra were recorded on a DPX-300 MHz Bruker FT-NMR spectrometer. The chemical shifts were reported as parts per million ( $\delta \mathrm{ppm})$ tetramethylsilane (TMS) as an internal standard. Mass spectra were obtained on a JEOL-SX-102 instrument using fast atom bombardment (FAB positive). Elemental analysis was performed on a Perkin-Elmer $2400 \mathrm{C}, \mathrm{H}, \mathrm{N}$ analyzer and values were within the acceptable limits of the calculated values. The progress of the reaction was monitored on readymade silica gel plates (Merck) using chloroformmethanol $(9: 1)$ as a solvent system. Iodine was used as a developing agent. Spectral data (IR, NMR and mass spectra) confirmed the structures of the synthesized compounds and the purity of these compounds was ascertained by microanalysis. Elemental $(\mathrm{C}, \mathrm{H}, \mathrm{N})$ analysis indicated that the calculated and observed values were within the acceptable limits $( \pm 0.4 \%)$. All chemicals and reagents were obtained from Aldrich (U.S.A.), Lancaster (U.K.) or Spectrochem Pvt.Ltd (India) and were used without further purification.

3-(4-Methoxyphenyl)-2-thioxo-2,3-dihydro-quinazolin-4(1H)-one (4) A solution of 4-methoxyaniline $1(2.46 \mathrm{~g}, 0.02 \mathrm{~mol})$ in dimethyl sulfoxide $(10 \mathrm{ml})$ was stirred vigorously. To this was added carbon disulphide $(1.98 \mathrm{~g}$, $0.026 \mathrm{~mol})$ and $20 \mathrm{M}$ aqueous sodium hydroxide solution $(1.2 \mathrm{ml})$ drop wise during $30 \mathrm{~min}$ with stirring. Dimethyl sulphate $(2.52 \mathrm{~g}, 0.02 \mathrm{~mol})$ was added gradually keeping the reaction mixture stirring in freezing mixture for $2 \mathrm{~h}$. The reaction mixture was then poured into ice water. The solid obtained was filtered, washed with water, dried and recrystallized from ethanol. Methyl anthranilate $(1.51 \mathrm{~g}, 0.01 \mathrm{~mol})$ and the above prepared $N$-(4-methoxyphenyl)methyl dithiocarbamic acid $(2.13 \mathrm{~g}, 0.01 \mathrm{~mol})$, were dissolved in ethanol $(20 \mathrm{ml})$. To this anhydrous potassium carbonate $(100 \mathrm{mg})$ was added and refluxed for $21 \mathrm{~h}$. The reaction mixture was cooled in ice and the solid separated was filtered and purified by dissolving in $10 \%$ alcoholic sodium hydroxide solution and reprecipitated by treating with dilute hydrochloric acid. The solid obtained was filtered, washed with water, dried and recrystallized from ethanol. Yield $=80 \%, \mathrm{mp} 296-300^{\circ} \mathrm{C}$. IR $(\mathrm{KBr}) \mathrm{cm}^{-1}: 3218(\mathrm{NH})$, $1680(\mathrm{C}=\mathrm{O}), 1593(\mathrm{C}=\mathrm{C}), 1200(\mathrm{C}=\mathrm{S}) ;{ }^{1} \mathrm{H}-\mathrm{NMR}\left(\mathrm{CDCl}_{3}\right) \delta(\mathrm{ppm}): 3.88$ $\left(\mathrm{s}, 3 \mathrm{H}, \mathrm{OCH}_{3}\right), 7.0-8.1(\mathrm{~m}, 8 \mathrm{H}, \mathrm{ArH}), 10.36(\mathrm{~s}, 1 \mathrm{H}, \mathrm{NH})$; MS $(\mathrm{m} / \mathrm{z}): 284$ $\left(\mathrm{M}^{+}\right)$. Anal. Calcd for $\mathrm{C}_{15} \mathrm{H}_{12} \mathrm{~N}_{2} \mathrm{O}_{2} \mathrm{~S}$ : C, 63.36; H, 4.25; N, 9.85. Found: C, $63.29 ; \mathrm{H}, 4.21 ; \mathrm{N}, 9.91$

2-Methylsulfanyl-3-(4-methoxyphenyl)-quinazolin-4(3H)-one (5) The 3-(4-methoxyphenyl)-2-thioxo-2,3-dihydro-quinazolin-4(1H)-one $4(2.84 \mathrm{~g}$, $0.01 \mathrm{~mol}$ ) was dissolved in $40 \mathrm{ml}$ of $2 \%$ alcoholic sodium hydroxide solution. To this dimethyl sulphate $(1.26 \mathrm{~g}, 0.01 \mathrm{~mol})$ was added drop wise with stirring. The stirring was continued for $1 \mathrm{~h}$, the reaction mixture was then poured into ice water. The solid obtained was filtered, washed with water, dried and recrystallized from ethanol-chloroform $(75: 25)$ mixture Yield $=78 \%, \mathrm{mp} 142-145^{\circ} \mathrm{C}$; IR $(\mathrm{KBr}) \mathrm{cm}^{-1}: 1683(\mathrm{C}=\mathrm{O}), 1610(\mathrm{C}=\mathrm{C})$; ${ }^{1} \mathrm{H}-\mathrm{NMR}\left(\mathrm{CDCl}_{3}\right) \delta(\mathrm{ppm}): 2.5\left(\mathrm{~s}, 3 \mathrm{H}, \mathrm{SCH}_{3}\right), 3.87\left(\mathrm{~s}, 3 \mathrm{H}, \mathrm{OCH}_{3}\right), 7.0$ $8.26(\mathrm{~m}, 8 \mathrm{H} \mathrm{ArH})$; MS $(\mathrm{m} / \mathrm{z})$ : $298\left(\mathrm{M}^{+}\right)$; Anal. Calcd for $\mathrm{C}_{16} \mathrm{H}_{14} \mathrm{~N}_{2} \mathrm{O}_{2} \mathrm{~S}: \mathrm{C}$, 64.41; H, 4.72; N, 9.38. Found: C, 64.53; H, 4.67; N, 9.45.

2-Hydrazino-3-(4-methoxyphenyl)-quinazolin-4(3H)-one (6) The 2methylsulfanyl-3-(4-methoxyphenyl)-quinazolin-4(3H)-one $\mathbf{5}$ (2.98 g, 0.01 $\mathrm{mol})$ was dissolved in ethanol $(25 \mathrm{ml})$. To this hydrazine hydrate $(99 \%)(5 \mathrm{~g}$, $0.1 \mathrm{~mol})$ and anhydrous potassium carbonate $(100 \mathrm{mg}$ ) was added and refluxed for $30 \mathrm{~h}$. The reaction mixture was cooled and poured into ice-water. The solid so obtained was filtered, washed with water, dried and recrystallized from chloroform-benzene $(25: 75)$ mixture. Yield $=74 \%, \mathrm{mp} 196$ $200^{\circ} \mathrm{C}$; IR $(\mathrm{KBr}) \mathrm{cm}^{-1}$ : 3350, $3320\left(\mathrm{NHNH}_{2}\right), 1674(\mathrm{C}=\mathrm{O}) ;{ }^{1} \mathrm{H}-\mathrm{NMR}$ $\left(\mathrm{CDCl}_{3}\right) \delta(\mathrm{ppm}): 3.79\left(\mathrm{~s}, 3 \mathrm{H}, \mathrm{OCH}_{3}\right), 4.95\left(\mathrm{~s}, 2 \mathrm{H}, \mathrm{NH}_{2}\right), 6.82-8.06(\mathrm{~m}$, $8 \mathrm{H}, \mathrm{ArH}), 8.56(\mathrm{~s}, 1 \mathrm{H}, \mathrm{NH})$; $\mathrm{MS}(\mathrm{m} / \mathrm{z}): 282\left(\mathrm{M}^{+}\right)$; Anal. Calcd for $\mathrm{C}_{15} \mathrm{H}_{14} \mathrm{~N}_{4} \mathrm{O}_{2}: \mathrm{C}, 63.82 ; \mathrm{H}, 4.99 ; \mathrm{N}, 19.84$. Found: $\mathrm{C}, 63.71 ; \mathrm{H}, 4.95 ; \mathrm{N}$, 19.93 .
2-(1-Methylpropylidene)-hydrazino-3-(4-methoxyphenyl)-quinazolin4(3H)-one (A1) A mixture of 2-hydrazino-3-(4-methoxyphenyl)-quinazolin-4(3H)-one $(6)(1.128 \mathrm{~g}, 0.288 \mathrm{~g}, 0.004 \mathrm{~mol})$ and ethylmethyl ketone $(0.004 \mathrm{~mol})$ in glacial acetic acid was refluxed for $36 \mathrm{~h}$. The reaction mixture was poured into ice water. The solid obtained was recrystallized from ethanol. Yield $=76 \%, \mathrm{mp} 218-219^{\circ} \mathrm{C}$. IR $(\mathrm{KBr}) \mathrm{cm}^{-1}: 3356(\mathrm{NH}), 1673$ $(\mathrm{C}=\mathrm{O}), 1610(\mathrm{C}=\mathrm{N}) .{ }^{1} \mathrm{H}-\mathrm{NMR}\left(\mathrm{CDCl}_{3}\right) \delta \mathrm{ppm}: 1.2-1.3\left(\mathrm{q}, 2 \mathrm{H}, \mathrm{CH}_{2} \mathrm{CH}_{3}\right)$, $1.6-1.7\left(\mathrm{t}, 3 \mathrm{H}, \mathrm{CH}_{2} \mathrm{CH}_{3}\right), 2.0-2.1\left(\mathrm{~s}, 3 \mathrm{H}, \mathrm{CH}_{3}\right), 3.2-3.3\left(\mathrm{~s}, 3 \mathrm{H}, \mathrm{OCH}_{3}\right)$, 7.0-7.7 (m, 8H, ArH), 8.2 (brs, 1H, NH). MS $(m / z): 336\left(\mathrm{M}^{+}\right)$. Anal. Calcd for $\mathrm{C}_{10} \mathrm{H}_{20} \mathrm{~N}_{4} \mathrm{O}_{2}: \mathrm{C}, 67.83 ; \mathrm{H}, 5.99 ; \mathrm{N}, 16.65$. Found: $\mathrm{C}, 67.86 ; \mathrm{H}$, 5.5.97; N, 16.61.

2-(1-Ethylpropylidene)-hydrazino-3-(4-methoxyphenyl)-quinazolin4(3H)-one (A2) Compound A2 was prepared by adopting the same procedure as for $\mathbf{A 1}$ and obtained in $73 \%$ yield, $\mathrm{mp} 243-245^{\circ} \mathrm{C}$. IR $(\mathrm{KBr}) \mathrm{cm}^{-1}$ : $3330(\mathrm{NH}), 1686(\mathrm{C}=\mathrm{O}), 1616(\mathrm{C}=\mathrm{N}) .{ }^{1} \mathrm{H}-\mathrm{NMR}\left(\mathrm{CDCl}_{3}\right) \delta \mathrm{ppm}: 1.0-1.2$ (m, 4H, $\left.\left(\mathrm{CH}_{2} \mathrm{CH}_{3}\right)_{2}\right), 1.5-1.7\left(\mathrm{~m}, 6 \mathrm{H},\left(\mathrm{CH}_{2} \mathrm{CH}_{3}\right)_{2}\right), 3.0\left(\mathrm{~s}, 3 \mathrm{H}, \mathrm{OCH}_{3}\right)$, 7.5-8.2 (m, 8H, ArH), 8.4 (brs, 1H, NH). MS $(\mathrm{m} / \mathrm{z}): 350\left(\mathrm{M}^{+}\right)$. Anal. Calcd for $\mathrm{C}_{20} \mathrm{H}_{22} \mathrm{~N}_{4} \mathrm{O}_{2}: \mathrm{C}, 68.55 ; \mathrm{H}, 6.32 ; \mathrm{N}, 15.98$. Found: C, 68.60; H, $6.36 ; \mathrm{N}, 15.95$.

2-(1-Methylbutylidene)-hydrazino-3-(4-methoxyphenyl)-quinazolin4(3H)-one (A3) Compound $\mathrm{A3}$ was prepared by adopting the same procedure as for $\mathbf{A 1}$ and obtained in $77 \%$ yield, $\mathrm{mp} 251-252^{\circ} \mathrm{C}$. IR $(\mathrm{KBr}) \mathrm{cm}^{-1}$ : $3260(\mathrm{NH}), 1687(\mathrm{C}=\mathrm{O}), 1618(\mathrm{C}=\mathrm{N}) .{ }^{1} \mathrm{H}-\mathrm{NMR}\left(\mathrm{CDCl}_{3}\right) \delta \mathrm{ppm}: 1.3-1.4$ (t, $2 \mathrm{H}, \mathrm{CH}_{2} \mathrm{CH}_{2} \mathrm{CH}_{3}$ ), 1.7-1.8 (sext, $2 \mathrm{H}, \mathrm{CH}_{2} \mathrm{CH}_{2} \mathrm{CH}_{3}$ ), 2.3-2.4 (t, $3 \mathrm{H}$, $\left.\mathrm{CH}_{2} \mathrm{CH}_{2} \mathrm{CH}_{3}\right), 2.8\left(\mathrm{~s}, 3 \mathrm{H}, \mathrm{CH}_{3}\right), 3.5\left(\mathrm{~s}, 3 \mathrm{H}, \mathrm{OCH}_{3}\right), 7.2-7.9(\mathrm{~m}, 9 \mathrm{H}, \mathrm{ArH})$, 8.2 (brs, $1 \mathrm{H}, \mathrm{NH})$. MS $(\mathrm{m} / \mathrm{z}): 350\left(\mathrm{M}^{+}\right)$. Anal. Calcd for $\mathrm{C}_{20} \mathrm{H}_{22} \mathrm{~N}_{4} \mathrm{O}_{2}: \mathrm{C}$, $68.55 ; \mathrm{H}, 6.32 ; \mathrm{N}, 15.98$. Found: C, 68.52; H, 6.37; N, 17.96.

2-( $N^{\prime}$-Cyclohexylidene-hydrazino)-3-(4-methoxyphenyl)-quinazolin4(3H)-one (A4) Compound $\mathrm{A} 4$ was prepared by adopting the same procedure as for $\mathbf{A 1}$ and obtained in $77 \%$ yield, $\mathrm{mp} 247-248^{\circ} \mathrm{C}$. IR $(\mathrm{KBr}) \mathrm{cm}^{-1}$ : $3230(\mathrm{NH}), 1690(\mathrm{C}=\mathrm{O}), 1616(\mathrm{C}=\mathrm{N}) .{ }^{1} \mathrm{H}-\mathrm{NMR}\left(\mathrm{CDCl}_{3}\right) \delta \mathrm{ppm}: 1.1-1.9$ (m, $10 \mathrm{H}$, cyclohexyl), $3.3\left(\mathrm{~s}, 3 \mathrm{H}, \mathrm{OCH}_{3}\right), 7.1-7.8(\mathrm{~m}, 8 \mathrm{H}, \mathrm{ArH}), 8.5$ (br s, $1 \mathrm{H}, \mathrm{NH})$. MS $(\mathrm{m} / \mathrm{z}): 362\left(\mathrm{M}^{+}\right)$. Anal. Calcd for $\mathrm{C}_{21} \mathrm{H}_{22} \mathrm{~N}_{4} \mathrm{O}_{2}: \mathrm{C}, 69.59 ; \mathrm{H}$, $6.11 ; \mathrm{N}, 15.45$. Found: C, 69.51; H, 6.08; N, 15.48 .

2-( $N^{\prime}$-1-Phenylethylidene-hydrazino)-3-(4-methoxyphenyl)-quinazolin-4(3H)-one (A5) Compound A5 was prepared by adopting the same procedure as for $\mathbf{A 1}$ and obtained in $77 \%$ yield, $\mathrm{mp} 273-274^{\circ} \mathrm{C}$. IR $(\mathrm{KBr})$ $\mathrm{cm}^{-1}: 3290(\mathrm{NH}), 1686(\mathrm{C}=\mathrm{O}), 1619(\mathrm{C}=\mathrm{N}) .{ }^{1} \mathrm{H}-\mathrm{NMR}\left(\mathrm{CDCl}_{3}\right) \delta \mathrm{ppm}: 1.1$ $\left(\mathrm{s}, 3 \mathrm{H}, \mathrm{CH}_{3}\right), 3.4\left(\mathrm{~s}, 3 \mathrm{H}, \mathrm{OCH}_{3}\right), 7.3-8.2(\mathrm{~m}, 13 \mathrm{H}, \mathrm{ArH}), 8.6(\mathrm{br} \mathrm{s}, 1 \mathrm{H}$, $\mathrm{NH})$. MS $(\mathrm{m} / z)$ : $384\left(\mathrm{M}^{+}\right)$. Anal. Calcd for $\mathrm{C}_{23} \mathrm{H}_{20} \mathrm{~N}_{4} \mathrm{O}_{2}: \mathrm{C}, 71.85 ; \mathrm{H}, 5.24$; $\mathrm{N}, 14.57$. Found: $\mathrm{C}, 71.89 ; \mathrm{H}, 5.26 ; \mathrm{N}, 14.62$.

2-(N'-2-Oxo-indolin-2-one-3-yl-idene-hydrazino)-3-(4-methoxyphenyl)-quinazolin-4(3H)-one (A6) Compound A6 was prepared by adopting the same procedure as for $\mathbf{A 1}$ and obtained in 79\% yield, mp 224$225^{\circ} \mathrm{C}$. IR $(\mathrm{KBr}) \mathrm{cm}^{-1}: 3280(\mathrm{NH}), 1680(\mathrm{C}=\mathrm{O}), 1615(\mathrm{C}=\mathrm{N}) .{ }^{1} \mathrm{H}-\mathrm{NMR}$ $\left(\mathrm{CDCl}_{3}\right) \delta$ ppm: $3.1\left(\mathrm{~s}, 3 \mathrm{H}, \mathrm{OCH}_{3}\right), 7.0-8.2(\mathrm{~m}, 12 \mathrm{H}, \mathrm{ArH}), 8.4(\mathrm{br} \mathrm{s}, 1 \mathrm{H}$, $\mathrm{NH}), 9.0($ br s, $1 \mathrm{H}, \mathrm{NH})$. MS $(\mathrm{m} / \mathrm{z})$ : $411\left(\mathrm{M}^{+}\right)$. Anal. Calcd for $\mathrm{C}_{23} \mathrm{H}_{17} \mathrm{~N}_{4} \mathrm{O}_{3}$ : C, 67.14; H, 4.16; N, 13.61. Found: C, 67.17; H, 4.18; N, 13.64 .

2-( $N^{\prime}$-Benzylidene-hydrazino)-3-(4-methoxyphenyl)-quinazolin4(3H)-one (A7) Compound $\mathrm{A} 7$ was prepared by adopting the same procedure as for $\mathbf{A 1}$ and obtained in $73 \%$ yield, $\mathrm{mp} 243-245^{\circ} \mathrm{C}$. IR $(\mathrm{KBr}) \mathrm{cm}^{-1}$ : $3310(\mathrm{NH}), 1686(\mathrm{C}=\mathrm{O}), 1610(\mathrm{C}=\mathrm{N}) .{ }^{1} \mathrm{H}-\mathrm{NMR}\left(\mathrm{CDCl}_{3}\right) \delta \mathrm{ppm}: 3.3(\mathrm{~s}$, $\left.3 \mathrm{H}, \mathrm{OCH}_{3}\right), 6.5(\mathrm{~s}, 1 \mathrm{H}, \mathrm{CH}), 7.1-8.2(\mathrm{~m}, 13 \mathrm{H}, \mathrm{ArH}), 8.7$ (br s, $\left.1 \mathrm{H}, \mathrm{NH}\right)$. MS $(\mathrm{m} / \mathrm{z}): 370\left(\mathrm{M}^{+}\right)$. Anal. Calcd for $\mathrm{C}_{22} \mathrm{H}_{18} \mathrm{~N}_{4} \mathrm{O}_{2}: \mathrm{C}, 71.33 ; \mathrm{H}, 4.89 ; \mathrm{N}$, 15.12. Found: C, 71.36; $\mathrm{H}, 4.86 ; \mathrm{N}, 15.14$.

2-( $N^{\prime}$-(2-Chloro-benzylidene-hydrazino))-3-(4-methoxyphenyl)-quinazolin-4(3H)-one (A8) Compound A8 was prepared by adopting the same procedure as for $\mathbf{A} 1$ and obtained in $79 \%$ yield, $\mathrm{mp} 263-264^{\circ} \mathrm{C}$. IR $(\mathrm{KBr})$ $\mathrm{cm}^{-1}: 3320(\mathrm{NH}), 1683(\mathrm{C}=\mathrm{O}), 1610(\mathrm{C}=\mathrm{N}) .{ }^{1} \mathrm{H}-\mathrm{NMR}\left(\mathrm{CDCl}_{3}\right) \delta \mathrm{ppm}: 3.2$ $\left(\mathrm{s}, 3 \mathrm{H}, \mathrm{OCH}_{3}\right), 6.3(\mathrm{~s}, 1 \mathrm{H}, \mathrm{CH}), 7.1-8.3(\mathrm{~m}, 12 \mathrm{H}, \mathrm{ArH}), 8.6(\mathrm{brs}, 1 \mathrm{H}, \mathrm{NH})$. MS $(m / z)$ : $405\left(\mathrm{M}^{+}\right)$. Anal. Calcd for $\mathrm{C}_{22} \mathrm{H}_{17} \mathrm{~N}_{4} \mathrm{O}_{2} \mathrm{Cl}: \mathrm{C}, 65.27 ; \mathrm{H}, 4.23 ; \mathrm{N}$, 13.84. Found: C, 65.21; H, 4.26; N, 13.88.

2-( $N^{\prime}$-(4-Chloro-benzylidene-hydrazino)-3-(4-methoxyphenyl)-quinazolin-4(3H)-one (A9) Compound A9 was prepared by adopting the same procedure as for $\mathbf{A 1}$ and obtained in $78 \%$ yield, $\mathrm{mp} 260-261^{\circ} \mathrm{C}$. IR $(\mathrm{KBr})$ $\mathrm{cm}^{-1}: 3270(\mathrm{NH}), 1687(\mathrm{C}=\mathrm{O}), 1616(\mathrm{C}=\mathrm{N}) .{ }^{1} \mathrm{H}-\mathrm{NMR}\left(\mathrm{CDCl}_{3}\right) \delta \mathrm{ppm}: 3.4$ $\left(\mathrm{s}, 3 \mathrm{H}, \mathrm{OCH}_{3}\right), 6.2(\mathrm{~s}, 1 \mathrm{H}, \mathrm{CH}), 7.0-8.1(\mathrm{~m}, 12 \mathrm{H}, \mathrm{ArH}), 8.4(\mathrm{brs}, 1 \mathrm{H}, \mathrm{NH})$. MS $(m / z): 405\left(\mathrm{M}^{+}\right)$. Anal. Calcd for $\mathrm{C}_{22} \mathrm{H}_{17} \mathrm{~N}_{4} \mathrm{O}_{2} \mathrm{Cl}: \mathrm{C}, 65.27 ; \mathrm{H}, 4.23 ; \mathrm{N}$, 13.84. Found: C, $65.33 ; \mathrm{H}, 4.21 ; \mathrm{N}, 13.81$.

2-( $N^{\prime}$-(2-Nitro-benzylidene-hydrazino)-3-(4-methoxyphenyl)-quinazolin-4(3H)-one (A10) Compound A10 was prepared by adopting the same procedure as for $\mathbf{A 1}$ and obtained in $73 \%$ yield, $\mathrm{mp} 237-239^{\circ} \mathrm{C}$. IR $(\mathrm{KBr}) \mathrm{cm}^{-1}: 3250(\mathrm{NH}), 1686(\mathrm{C}=\mathrm{O}), 1620(\mathrm{C}=\mathrm{N}) .{ }^{1} \mathrm{H}-\mathrm{NMR}\left(\mathrm{CDCl}_{3}\right) \delta$ ppm: $3.2\left(\mathrm{~s}, 3 \mathrm{H}, \mathrm{OCH}_{3}\right), 6.1(\mathrm{~s}, 1 \mathrm{H}, \mathrm{CH}), 7.3-8.2(\mathrm{~m}, 12 \mathrm{H}, \mathrm{ArH}), 8.5$ (br s, 
1H, NH). MS $(m / z): 415\left(\mathrm{M}^{+}\right)$. Anal. Calcd for $\mathrm{C}_{22} \mathrm{H}_{17} \mathrm{~N}_{5} \mathrm{O}_{4}: \mathrm{C}, 63.61 ; \mathrm{H}$, 4.12; N, 16.86. Found: C, 63.67; H, 4.15; N, 16.82 .

2-( $N^{\prime}$-(4-Nitro-benzylidene-hydrazino))-3-(4-methoxyphenyl)-quinazolin-4(3H)-one (A11) Compound A11 was prepared by adopting the same procedure as for $\mathbf{A 1}$ and obtained in $77 \%$ yield, $\mathrm{mp} 231-233^{\circ} \mathrm{C}$. IR $(\mathrm{KBr}) \mathrm{cm}^{-1}: 3293(\mathrm{NH}), 1687(\mathrm{C}=\mathrm{O}), 1616(\mathrm{C}=\mathrm{N}) .{ }^{1} \mathrm{H}-\mathrm{NMR}\left(\mathrm{CDCl}_{3}\right) \delta$ ppm: $3.4\left(\mathrm{~s}, 3 \mathrm{H}, \mathrm{OCH}_{3}\right), 6.3(\mathrm{~s}, 1 \mathrm{H}, \mathrm{CH}), 7.0-8.2(\mathrm{~m}, 12 \mathrm{H}, \mathrm{ArH}), 8.7(\mathrm{br} \mathrm{s}$, $1 \mathrm{H}, \mathrm{NH})$. MS $(\mathrm{m} / \mathrm{z}): 415\left(\mathrm{M}^{+}\right)$. Anal. Calcd for $\mathrm{C}_{22} \mathrm{H}_{17} \mathrm{~N}_{5} \mathrm{O}_{4}: \mathrm{C}, 63.61 ; \mathrm{H}$, 4.12 ; N, 16.86. Found: C, $63.65 ; \mathrm{H}, 4.14 ; \mathrm{N}, 16.83$.

2-(N'-(4-Methoxy-benzylidene-hydrazino))-3-(4-methoxyphenyl)quinazolin-4(3H)-one (A12) Compound A12 was prepared by adopting the same procedure as for $\mathbf{A 1}$ and obtained in $73 \%$ yield, $\mathrm{mp} 256-258^{\circ} \mathrm{C}$. IR $(\mathrm{KBr}) \mathrm{cm}^{-1}: 3276(\mathrm{NH}), 1683(\mathrm{C}=\mathrm{O}), 1611(\mathrm{C}=\mathrm{N}) .{ }^{1} \mathrm{H}-\mathrm{NMR}\left(\mathrm{CDCl}_{3}\right) \delta$ ppm: $2.7\left(\mathrm{~s}, 3 \mathrm{H}, \mathrm{OCH}_{3}\right), 3.3\left(\mathrm{~s}, 3 \mathrm{H}, \mathrm{OCH}_{3}\right), 6.5(\mathrm{~s}, 1 \mathrm{H}, \mathrm{CH}), 7.0-8.2(\mathrm{~m}$, $12 \mathrm{H}, \mathrm{ArH}), 8.5(\mathrm{brs}, 1 \mathrm{H}, \mathrm{NH})$. MS $(\mathrm{m} / \mathrm{z}): 400\left(\mathrm{M}^{+}\right)$. Anal. Calcd for $\mathrm{C}_{23} \mathrm{H}_{20} \mathrm{~N}_{4} \mathrm{O}_{3}: \mathrm{C}, 68.99 ; \mathrm{H}, 5.03 ; \mathrm{N}, 13.99$. Found: $\mathrm{C}, 68.94 ; \mathrm{H}, 5.07 ; \mathrm{N}$, 13.96.

2-( $N^{\prime}$-(2-Methyl-benzylidene-hydrazino))-3-(4-methoxyphenyl)-quinazolin-4(3H)-one (A13) Compound A13 was prepared by adopting the same procedure as for $\mathbf{A 1}$ and obtained in $76 \%$ yield, $\mathrm{mp} 230-232{ }^{\circ} \mathrm{C}$. IR $(\mathrm{KBr}) \mathrm{cm}^{-1}: 3318(\mathrm{NH}), 1684(\mathrm{C}=\mathrm{O}), 1615(\mathrm{C}=\mathrm{N}) .{ }^{1} \mathrm{H}-\mathrm{NMR}\left(\mathrm{CDCl}_{3}\right) \delta$ ppm: $2.3\left(\mathrm{~s}, 3 \mathrm{H}, \mathrm{CH}_{3}\right), 3.1\left(\mathrm{~s}, 3 \mathrm{H}, \mathrm{OCH}_{3}\right), 6.2(\mathrm{~s}, 1 \mathrm{H}, \mathrm{CH}), 7.0-8.1(\mathrm{~m}$, $12 \mathrm{H}, \operatorname{ArH}), 8.4(\mathrm{~s}, 1 \mathrm{H}, \mathrm{NH})$. MS $(\mathrm{m} / \mathrm{z}): 384\left(\mathrm{M}^{+}\right)$. Anal. Calcd for $\mathrm{C}_{23} \mathrm{H}_{20} \mathrm{~N}_{4} \mathrm{O}_{2}: \mathrm{C}, 71.86 ; \mathrm{H}, 5.24 ; \mathrm{N}, 14.57$. Found: $\mathrm{C}, 71.82 ; \mathrm{H}, 5.25 ; \mathrm{N}$, 14.60 .

2-( $N^{\prime}$-(4-Methyl-benzylidene-hydrazino)-3-(4-methoxyphenyl)-quinazolin-4(3H)-one (A14) Compound A14 was prepared by adopting the same procedure as for $\mathbf{A 1}$ and obtained in $76 \%$ yield, $\mathrm{mp} 258-259^{\circ} \mathrm{C}$. IR $(\mathrm{KBr}) \mathrm{cm}^{-1}: 3240(\mathrm{NH}), 1692(\mathrm{C}=\mathrm{O}), 1616(\mathrm{C}=\mathrm{N}) .{ }^{1} \mathrm{H}-\mathrm{NMR}\left(\mathrm{CDCl}_{3}\right) \delta$ ppm: $2.1\left(\mathrm{~s}, 3 \mathrm{H}, \mathrm{CH}_{3}\right), 3.3\left(\mathrm{~s}, 3 \mathrm{H}, \mathrm{OCH}_{3}\right), 6.6\left(\mathrm{~s}, 3 \mathrm{H}, \mathrm{CH}_{3}\right), 7.3-8.4(\mathrm{~m}$, $12 \mathrm{H}, \mathrm{ArH}), 8.6(\mathrm{brs}, 1 \mathrm{H}, \mathrm{NH})$. MS $(\mathrm{m} / \mathrm{z}): 384\left(\mathrm{M}^{+}\right)$. Anal. Calcd for $\mathrm{C}_{23} \mathrm{H}_{20} \mathrm{~N}_{4} \mathrm{O}_{2}: \mathrm{C}, 71.86 ; \mathrm{H}, 5.24 ; \mathrm{N}, 14.57$. Found: $\mathrm{C}, 71.82 ; \mathrm{H}, 5.27 ; \mathrm{N}$, 14.61 .

2-( $N^{\prime}$-Phenyl-benzylidene-hydrazino)-3-(4-methoxyphenyl)-quinazolin-4(3H)-one (A15) Compound A15 was prepared by adopting the same procedure as for $\mathbf{A 1}$ and obtained in $79 \%$ yield, $\mathrm{mp} 251-253^{\circ} \mathrm{C}$. IR $(\mathrm{KBr}) \mathrm{cm}^{-1}: 3270(\mathrm{NH}), 1692(\mathrm{C}=\mathrm{O}), 1613(\mathrm{C}=\mathrm{N}) .{ }^{1} \mathrm{H}-\mathrm{NMR}\left(\mathrm{CDCl}_{3}\right) \delta$ ppm: 3.5 (s, $\left.3 \mathrm{H}, \mathrm{OCH}_{3}\right), 7.1-8.4(\mathrm{~m}, 18 \mathrm{H}, \mathrm{ArH}), 8.7$ (brs, $\left.1 \mathrm{H}, \mathrm{NH}\right)$. MS $(\mathrm{m} / \mathrm{z}): 446\left(\mathrm{M}^{+}\right)$. Anal. Calcd for $\mathrm{C}_{28} \mathrm{H}_{22} \mathrm{~N}_{4} \mathrm{O}_{2}: \mathrm{C}, 75.32 ; \mathrm{H}, 4.97 ; \mathrm{N}, 12.55$ Found: C, 75.38; H, 4.92; N, 12.56 .

Pharmacology The synthesized compounds were evaluated for analgesic, anti-inflammatory, ulcerogenicindex and antimicrobial activities. Student $t$-test was performed to ascertain the significance of all the exhibited activities. The test compounds and the standard drugs were administered in the form of a suspension ( $1 \%$ carboxy methyl cellulose as a vehicle) by oral route of administration for analgesic and anti-inflammatory but for ulcerogenicity studies by intra peritoneally as suspension in $10 \% \mathrm{v} / \mathrm{v}$ Tween. Each group consisted of six animals. The animals were procured from the Tetrex Biological Center, Madurai, India, and were maintained in colony cages at $25 \pm 2{ }^{\circ} \mathrm{C}$, relative humidity of $45-55 \%$, under a $12 \mathrm{~h}$ light and dark cycle; they were fed standard animal feed. All the animals were acclimatized for a week before use. The Institutional Animal Ethics committee approved the protocol adopted for the experimentation of animals.

Analgesic Activity Test for analgesic activity was performed by tailflick technique $\left.{ }^{14,15}\right)$ using Wistar albino mice $(25-35 \mathrm{~g})$ of either sex selected by random sampling technique. Diclofenac sodium at a dose level of $10 \mathrm{mg} / \mathrm{kg}$ and $20 \mathrm{mg} / \mathrm{kg}$ was administered orally as reference drug for comparison. The test compounds at two dose levels $(10,20 \mathrm{mg} / \mathrm{kg})$ were administered orally. The reaction time was recorded at $30 \mathrm{~min}, 1,2$ and $3 \mathrm{~h}$ after the treatment, and cut-off time was $10 \mathrm{~s}$. The percent analgesic activity (PAA) was calculated by the following formula,

$$
\mathrm{PAA}=\left[\frac{T_{2}-T_{1}}{10-T_{1}}\right] \times 100
$$

where $T_{1}$ is the reaction time (s) before treatment, and $T_{2}$ is the reaction time (s) after treatment.

Anti-inflammatory Activity Anti-inflammatory activity was evaluated by carrageenan-induced paw oedema test in rats. ${ }^{16)}$ Diclofenac sodium 10 , $20 \mathrm{mg} / \mathrm{kg}$ was administered as a standard drug for comparison. The test compounds were administered at two dose levels $(10 \mathrm{mg}, 20 \mathrm{mg} / \mathrm{kg})$. The paw volumes were measured using the mercury displacement technique with the help of a plethysmograph immediately before and $30 \mathrm{~min}, 1,2$ and $3 \mathrm{~h}$ after carrageenan injection. The percent inhibition of paw oedema was calculated using the following formula

percent inhibition $I=100[1-(a-x) /(b-y)]$

Where $x$ is the mean paw volume of rats before the administration of carrageenan and test compounds or reference compound (test group), $a$ is the mean paw volume of rats after the administration of carrageenan in the test group (drug treated), $b$ is the mean paw volume of rats after the administration of carrageenan in the control group, $y$ is the mean paw volume of rats before the administration of carrageenan in the control group.

Evaluation of Ulcerogenicity Index Ulceration in rats was induced as described by Goyal et al. ${ }^{17)}$ Albino rats of wistar strain weighing $150-200 \mathrm{~g}$ of either sex were divided into various groups each of six animals. Control group of animals were administered only with $10 \% \mathrm{v} / \mathrm{v}$ Tween 80 suspension intraperitonially. One group was administered with Aspirin (German Remedies) intraperitoneally in a dose of $20 \mathrm{mg} / \mathrm{kg}$ once daily for $3 \mathrm{~d}$. The remaining group of animals was administered with test compounds intraperitoneally in a dose of $20 \mathrm{mg} / \mathrm{kg}$. On fourth day, pylorus was ligated as per the method of Shay et al. ${ }^{18)}$ Animals were fasted for $36 \mathrm{~h}$ before the pylorus ligation procedure. Four hours after the ligation, animals were sacrificed. The stomach was removed and opened along with the greater curvature. Ulcer index was determined by the method of Ganguly and Bhatnagar ${ }^{19)}$ and recorded in Table 3 .

Statistical Analysis Statistical analysis of the biological activity of the synthesized compounds on animals was evaluated using a one-way analysis of variance (ANOVA). In all cases, post-hoc comparisons of the means of individual groups were performed using Tukey's test. A significance level of $p<0.05$ denoted significance in all cases. All values are expressed as mean \pm S.D. (standard deviations). For statistical analysis we have used GraphPad Prism 3.0 version. (GraphPad Prism 3.0 version, GraphPad Software, Inc.11452 El Camino Real, \#215, San Diego, CA 92130 U.S.A.).

\section{References}

1) Vane J. R., Botting R. M., Inflamm. Res., 47, 578-587 (1998).

2) Ryn J. V., Trummlitz G., Pairet M., Curr. Med. Chem., 7, 1145-1161 (2000).

3) Carter J. S., Expert Opin. Ther. Pat., 10, 1011-1020 (2000).

4) Beuck M., Angew. Chem., Int. Ed., 38, 631-633 (1999).

5) Alagarsamy V., Meena S., Revathi R., Vijayakumar S., Ramseshu K. V., Pharmazie, 58, 4-8 (2003).

6) Alagarsamy V., Thanga Thirupathy A., Mandal S. C., Rajasekaran S., Vijayakumar S., Revathi R., Anburaj J., Arunkumar S., Rajesh S., Indian J. Pharm. Sci., 68, 108-111 (2006).

7) Srivastava B. M., Bhalla V. K., Shankar T. N., Arzneim.-Forsch., 43, 595-600 (1993).

8) Hitkari A., Saxena M., Verma A. K., Gupta M., Shankar M. P., Bull. Chim. Farm., 134, 609-615 (1995).

9) Ibrahim M. K., Al Azhar, J. Pharm. Sci., 22, 9-12 (1998).

10) Alagarsamy V., Raja Solomon V., Vanikavitha G., Paluchamy V., Ravichandran M., Arnald Sujin A., Thangathirupathy A., Amuthalakshmi S., Revathi R., Biol. Pharm. Bull., 25, 1432-1435 (2002).

11) Alagarsamy V., Murugananthan G., Venkateshperumal R., Biol. Pharm. Bull., 26, 1711-1714 (2003).

12) Alagarsamy V., Rajesh R., Meena R., Vijaykumar S., Ramseshu K. V., Durai Anandakumar T., Biol. Pharm. Bull., 27, 652-656 (2004).

13) Alagarsamy V., Muthukumar V., Pavalarani N., Vasanthanathan P., Revathi R., Biol. Pharm. Bull., 26, 557-559 (2003).

14) Kulkarni S. K., Life Sci., 27, 185-188 (1980).

15) Amour R. E., Smith D. L., J. Pharmacol. Exp. Ther., 72, 74-78 (1941).

16) Winter C. A., Risely E. A., Nu G. N., Proc. Soc. Exp. Biol., 111, 544-547 (1982).

17) Goyal R. K., Chakrabarthi A., Sanyal A. K., Planta Medica, 29, 8588 (1985).

18) Shay H., Komarov S. A., Fels S. E., Mmeraze D., Gruenstei M., Siplet H., Gastroenterology, 5, 43-61 (1945).

19) Ganguly A. K., Bhatnagar O. P., Canadian J. Physiol. Pharmacol., 51, $748-750$ (1973). 